\title{
TINDAK TUTUR DIREKTIF DALAM NOVEL SUSAH SINYAL KARYA IKA NATASSA \& ERNEST PRAKASA \\ (KAJIAN PRAGMATIK)
}

\author{
Aska Rizkia Murti ${ }^{1}$ \\ Zamzam Nurhuda ${ }^{2}$ \\ Dosen01085@unpam.ac.id
}

\begin{abstract}
Abstrak
Penelitian ini bertujuan untuk (1) mendeskripsikan fungsi-fungsi tindak tutur direktif dalam dialog novel Susah Sinyal karya Ika Natassa dan Ernest Prakasa. (2) mendeskripsikan modus kalimat pada tindak tutur direktif dalam dialog novel Susah Sinyal karya Ika Natassa dan Ernest Prakasa. Penelitian ini menggunakan metode penelitian deskriptif kualitatif. Objek yang diteliti dalam penelitian ini adalah tuturan yang terdapat dalam novel Susah Sinyal karya Ika Natassa dan Ernest Prakasa. Data yang ditemukan berjumlah 40 data yang diperoleh dengan menggunakan teknik baca dan catat dalam teknik pengumpulan data. Berdasarkan analisis data yang diperoleh, dapat diberi kesimpulan: (1) Fungsi tindak tutur direktif yang ditemukan dalam novel Susah Sinyal karya Ika Natassa dan Ernest Prakasa yaitu fungsi meminta 2 data, memohon 1 data, mengajak 4 data, bertanya 24 data, memerintah 1 data, menuntut 2 data, melarang 2 data, membolehkan 1 data, memaafkan 1 data, menasehatkan 1 data, mengusulkan dan menyarankan 1 data. (2) Modus kalimat pada tindak tutur direktif yang ditemukan dalam novel Susah Sinyal karya Ika Natassa dan Ernest Prakasa yaitu modus kalimat berita, tanya, perintah dan kalimat tanya \& perintah. Data yang mengandung modus kalimat tersebut antara lain yaitu kalimat berita 11 data, kalimat tanya 25 data, kalimat perintah 1 data dan kalimat tanya $\&$ perintah 3 data.
\end{abstract}

Kata kunci: Fungsi dan modus kalimat pada tindak tutur direktif, Pragmatik, novel Susah Sinyal.

\footnotetext{
${ }^{1}$ Mahasiswa Program Studi Sastra Indonesia Universitas Pamulang, email: askarizkia5@gmail.com

${ }^{2}$ Dosen Tetap Universitas Pamulang, email: izam_albukhori@yahoo.co.id
} 


\section{Pendahuluan}

Bahasa adalah identitas diri manusia dengan lingkungannya. Bahasa merupakan unsur yang tidak dapat dipisahkan dari manusia dalam kehidupan sehari-hari, nikasi yang digunakan oleh masyarakat untuk berinteraksi dengan sesama. Otomatis manusia dapat berkomunikasi dan berinteraksi dengan masyarakat sekitar melalui bahasa. Pada saat berkomunikasi, manusia baik secara langsung maupun tidak langsung saling menyampaikan informasi yang didapat berupa pikiran, gagasan, maksud, perasaan, maupun emosinya.

Chaer (2010: 15) mengatakan bahwa bahasa digunakan oleh penuturnya untuk berkomunikasi atau berinteraksi dalam suatu tuturan. Dalam berkomunikasi manusia menggunakan tuturan-tuturan untuk mengutarakan apa yang ingin disampaikan. Kegiatan berkomunikasi dapat terlihat dalam wujud kegiatan bertutur yang selalu hadir dalam kehidupan bermasyarakat. Pada hakikatnya, komunikasi bukan hanya sekedar penyampaian bahasa melalui kata-kata melainkan selalu disertai dengan perilaku atau tindakan. Tindakan manusia ketika mengucapkan tuturan atau ujaran disebut dengan tindak tutur. Chaer (2010: 27) mengatakan bahwa tindak tutur adalah tuturan dari seseorang yang bersifat psikologis dan yang dilihat dari makna tindakan dalam tuturannya itu. Bersifat psikologis karena tuturan yang timbul tersebut berasal dan tertanam dari dalam jiwa seseorang itu sendiri dan merupakan aplikasi dari kepribadian mereka.

Tindak tutur merupakan dasar bagi analisis topik pragmatik. Pragmatik adalah kajian tentang bagaimana bahasa digunakan untuk berkomunikasi, dan menegaskan bahwa pragmatik tidak menelaah struktur bahasa secara internal seperti tata bahasa, melainkan secara eksternal yaitu bagaimana bahasa itu digunakan dalam komunikasi sehari-hari. Keberhasilan komunikasi terjadi apabila terjadi kesepahaman penutur dan lawan tutur atau dengan kata lain si penutur dapat memahami maksud tuturan (Nadar, 2008: 4). Dalam pragmatik, konteks sangatlah penting. Hal tersebut ditekankan oleh Wijana (dalam Nadar, 2008: 4) yang menyatakan bahwa pragmatik mengkaji makna yang terikat konteks. Konteks ini didefinisikan sebagai latar belakang pemahaman yang dimiliki oleh penutur atau lawan tutur sehingga lawan tutur dapat membuat interpretasi mengenai apa yang dimaksud oleh penutur pada waktu membuat tuturan tertentu 
(Nadar, 2008: 6). Jadi, makna yang dikaji pragmatik adalah makna yang terikat konteks atau dengan kata lain mengkaji maksud penutur untuk memahami maksud lawan tutur.

Tindak tutur merupakan gejala individu yang bersifat psikologis dan ditentukan oleh kemampuan bahasa penutur dalam menghadapi situasi tertentu. Jenis-jenis tindak tutur itu sendiri antara lain; 1) konstatif dan performatif, 2) lokusi, ilokusi dan perlokusi, 3) representatif, direktif, ekspresif, komisif, dan deklarasi, 4) langsung, tidak langsung, harfiah, tidak harfiah, dan vernakuler dan seremonial. Keharmonisan berkomunikasi yang menjaga perasaan sangat diutamakan dalam bentuk komunikasi tertentu. Hal ini akan menentukan tujuan dan harapan yang diperoleh dari komunikasi tersebut. Namun dalam komunikasi, yang mempertimbangkan adanya efek rasa adalah tuturan direktif. Oleh sebab itu dalam skripsi ini penulis membatasi dengan hanya membahas tindak tutur direktif. Tindak tutur direktif tersebut antara lain seperti, meminta, memohon, memerintah, menuntut, menasihatkan, menyarankan, dan lain-lain yang perlu mengutamakan adanya keharmonisan hubungan antara penutur dan mitra tutur.

Di dalam tindak tutur direktif bahasa tidak hanya membuat pendengar melakukan sesuatu, tetapi melakukan kegiatan sesuai dengan yang dikehendaki pembicara. Tindak tutur direktif menurut Searle (dalam Ibrahim, 1993: 29) memiliki fungsi yang bermacam-macam. Fungsi tindak tutur direktif tersebut meliputi, Requestives questions, requirements prohibitives permissives, dan Advisories.

Tindak tutur seperti buat gue dong!, sering ditemui dalam karya sastra. Salah satunya, yaitu novel. Di dalam penelitian ini, penulis memilih novel sebagai objek penelitian. Novel tersebut yaitu novel Susah Sinyal yang merupakan karya kolaborasi Ika Natassa dan Ernest Prakasa adalah novel yang dijadikan objek penelitian penulis. Novel ini menceritakan tentang seorang single parent yaitu Ellen, merupakan seorang pengacara dengan karir yang cukup sukses. Namun, kesuksesannya tidak didukung oleh kesuksesan dalam menjuarai hati sang anak, Kiara. Seorang remaja yang penuh dengan siasat pemberontakan.

Di dalam penelitian ini, penulis mengambil tuturan yang terjadi pada dialog di dalam novel Susah Sinyal karena di dalamnya terdapat banyak tuturan direktif yang menarik untuk diteliti lebih dalam. Dengan adanya beragam tuturan direktif yang ada pada novel Susah Sinyal ini memudahkan penulis untuk mengidentifikasi tindak tutur terkait. Berikut ini contoh tindak tutur direktif dalam dialog novel Susah Sinyal. 


\section{Data (001) :}

Jessie: "Eh, betewe, headband lo ini masih ada nggak? Buat gue dong!"

Kiara tersenyum tengil.

Kiara: "Minta dibikinin sama oma lo dong". (SS, 2018: 19)

Konteks tuturan data (001), aktivitas yang berlangsung yakni ketika bel istirahat berbunyi dan siswa-siswa berhamburan keluar, kecuali penutur dan mitra tutur. Penutur dan mitra tutur berhubungan akrab sebagai teman sebangku di kelas. Penutur bernama Jessie dan mitra tutur bernama Kiara, dalam konteks tersebut, Jessie meminta kepada Kiara agar Kiara mau memberikan headband miliknya kepada Jessie. Namun Kiara meresponnya dengan menjawab seperti yang terdapat pada dialog di atas.

Tindak tutur direktif dalam data (001) adalah tindak tutur Requestives yang berfungsi meminta. Menurut Searle (dalam Ibrahim, 1993: 28) direktif dengan fungsi meminta adalah untuk mengekspresikan keinginan bahwa mitra tutur melakukan sesuatu, dan dengan maksud bahwa mitra tutur melakukan sesuatu tersebut oleh karena (paling tidak sebagian) keinginan penutur.

Oleh karena itu, alasan penulis mengambil judul "Tindak Tutur Direktif dalam Novel Susah Sinyal karya Ika Natassa dan Ernest Prakasa" adalah karena tindak tutur direktif banyak ditemukan di tengah masyarakat, terdapat banyak tuturan direktif dalam novel Susah Sinyal yang menarik untuk diteliti lebih dalam, dan karena dari novel Susah Sinyal terdapat banyak masalah dan konflik antara penutur dengan mitra tutur yang menimbulkan tuturan direktif di dalamnya, sehingga memudahkan penulis mengidentifikasi tindak tutur terkait.

\section{Metode Penelitian}

Penelitian ini menggunakan metode kualitatif. Metode kualitatif adalah metode yang berkaitan dengan data yang tidak berupa angka tetapi berupa kualitas bentukbentuk variabel yang berwujud tuturan sehingga data yang dihasilkan berupa kata-kata tertulis atau lisan tentang sifat-sifat individu, keadaan, gejala, dari kelompok tertentu yang diamati (Moleong, 2010: 6). Penulis menggunakan metode kualitatif karena data penelitian berupa bentuk-bentuk verbal bahasa yaitu berupa tuturan yang dilakukan oleh 
para tokoh yang terdapat dalam novel Susah Sinyal karya Ika Natassa dan Ernest Prakasa.

Selain metode kualitatif juga digunakan metode deskriptif pada penelitian ini. Metode tersebut adalah suatu metode yang berupaya mengungkapkan sesuatu secara apa adanya (Sudaryanto, 1992: 62). Pada penelitian ini penelitian yang dilakukan sematamata hanya berdasarkan pada fakta yang ada atau fenomena yang secara empiris hidup pada penuturnya, sehingga yang dihasilkan berupa bahasa yang biasa dilakukan sifatnya.

Sumber data yang digunakan dalam penelitian ini adalah sumber data primer dan sumber data sekunder. Sumber data primer dalam penelitian ini adalah sebuah novel Susah Sinyal karya Ika Natassa dan Ernest Prakasa yang diterbitkan pertama kali oleh PT Gramedia Pustaka Utama di Jakarta pada tahun 2018 dengan tebal 272 halaman; 20 $\mathrm{cm}$. Sedangkan data sekunder dalam penelitian ini didapat dari beberapa referensi yaitu jurnal, novel dan buku yang terkait dengan pembahasan "Tindak Tutur Direktif”.

\section{Pembahasan}

Sesuai dengan fokus penelitian penulis, maka pembahasan dalam penelitian ini mencakup fungsi dan modus kalimat pada tuturan direktif. Penelitian ini menggunakan objek karya sastra, yaitu novel. Penulis menemukan sebanyak 40 data yang terdapat tindak tutur direktif di dalam novel Susah Sinyal. Data hasil penelitian ini diambil saat penulis membaca novel tersebut.

\section{Fungsi Tindak Tutur Direktif dalam Novel Susah Sinyal}

Setelah dilakukan penelitian, ditemukan 12 fungsi tindak tutur direktif yang terdapat dalam novel Susah Sinyal karya Ika Natassa dan Ernest Prakasa yaitu sebagai berikut:

\section{a. Fungsi Tindak Tutur Direktif Meminta}

Penulis menemukan 2 data yang termasuk dalam fungsi tindak tutur direktif meminta yang ditemukan dalam novel Susah Sinyal karya Ika Natassa dan Ernest Prakasa. Diantaranya penulis analisis sebagai berikut:

\section{Data (001)}

Jessie: "Eh, betewe, headband lo ini masih ada nggak? Buat gue dong!"

Kiara tersenyum tengil. 
Kiara: "Minta dibikinin sama oma lo dong". (SS, 2018: 19)

Tuturan data (001) terjadi di dalam kelas ketika jam istirahat. Penutur bermaksud meminta mitra tutur untuk memberikan sesuatu kepada mitra tutur. Dalam tuturan tersebut penutur mengucapkan "headband lo masih ada nggak? buat gue dong!".

Berdasarkan konteks tuturannya, tuturan data (001) termasuk dalam fungsi tindak tutur direktif meminta. Tuturan dituturkan oleh penutur kepada mitra tutur dengan intonasi yang sedang, dengan suasana yang santai. Tuturan tersebut diungkapkan melalui bahasa tulis. Tuturan yang diucapkan menggunakan norma kesopanan dalam berkomunikasi antara si penutur dengan mitra tutur, seperti pada dialog di atas, Jessie meminta kepada Kiara untuk memberikan ikat kepala (headband) milik Kiara kepadanya dan Kiara merespon keinginan Jessie dengan menjawab minta bikinin aja sama oma lo. Dari respon tuturan Kiara tersebut, dapat diketahui bahwa Kiara tidak mengiyakan keinginan Jessie dengan tidak memberikan headband miliknya kepada Jessie. Tuturan direktif dalam dialog novel Susah Sinyal diwujudkan dalam dialog antara penutur dengan mitra tutur.

Fungsi tindak tutur direktif meminta dalam novel Susah Sinyal Karya Ika Natassa dan Ernest Prakasa, terdapat juga pada:

\section{Data (002)}

Ellen: “Ki, dengerin Mama dulu, please," pintanya.

Berdasarkan analisis konteks di atas, tuturan "Ki, dengerin Mama dulu, please," pada dialog data (002) termasuk ke dalam fungsi tidak tutur direktif meminta. Meminta merupakan tuturan yang memiliki maksud agar apa yang diinginkan penutur dapat dipenuhi oleh mitra tutur. Dalam dialog tersebut, fungsi tuturan meminta digunakan Ellen yang menginginkan Kiara untuk mendengar penjelasannya mengenai masalah yang telah terjadi saat itu dan memaafkan dirinya. Permintaan Ellen tersebut direspon Kiara dengan jawaban yang terdapat pada dialog data (002). Tuturan tersebut dituturkan secara langsung melalui dialog antara Ellen dan Kiara dalam novel Susah Sinyal.

\section{b. Fungsi Tindak Tutur Direktif Memohon}

Fungsi memohon digunakan oleh penutur untuk mengekspresikan kata-kata permohonan atas suatu hal dengan hormat secara sopan dan santun kepada mitra tutur. Pada tuturan memohon ini penutur menginginkan kerendahan hati mitra tutur agar mau 
melakukan dan memenuhi apa yang diinginkan oleh penutur. Penulis menemukan 1 data yang termasuk dalam fungsi tindak tutur direktif memohon yang ditemukan dalam novel Susah Sinyal karya Ika Natassa dan Ernest Prakasa. Data tersebut penulis analisis sebagai berikut:

\section{Data (003)}

Kiara: “Oma, ayo dong”. Kiara menarik tangan neneknya ke kamar.

Oma Agatha:“Duh, Ki, males ah!”. (SS, 2018: 7)

Berdasarkan analisis konteks di atas, tuturan "Oma ayo dong" pada dialog data (003) termasuk ke dalam fungsi memohon. Memohon merupakan tuturan yang memiliki maksud meminta dengan hormat kepada mitra tutur agar apa yang diinginkan oleh penutur dengan kerendahan hati dipenuhi oleh mitra tutur. Dalam dialog data (003) fungsi tuturan memohon digunakan oleh Kiara yang menginginkan Oma ikut bersamanya ke kamar untuk bernyanyi bersama. Tuturan tersebut dituturkan secara langsung melalui dialog antara Kiara dengan Oma dalam novel Susah Sinyal.

\section{c. Fungsi Tindak Tutur Direktif Mengajak}

Fungsi mengajak digunakan oleh penutur untuk mengekspresikan kata-kata ajakan melakukan sesuatu agar diikuti oleh mitra tutur. Pada tuturan mengajak ini penutur menginginkan mitra tutur agar mau mengikuti apa yang diinginkan oleh penutur. Penulis menemukan 4 data yang termasuk dalam fungsi tindak tutur direktif mengajak yang ditemukan dalam novel Susah Sinyal karya Ika Natassa dan Ernest Prakasa. Beberapa diantaranya penulis analisis sebagai berikut:

\section{Data (004)}

Ellen: "Yuk, balik kantor ah".

Iwan: "Bentar, gue ke toilet dulu ya. Daripada nanti macet terus gue pipis di botol di mobil lo kan nggak lucu," seru Iwan sambil setengah berlari. (SS, 2018: 25)

Berdasarkan analisis konteks di atas, tuturan "yuk, balik kantor ah" pada dialog data (004) termasuk ke dalam fungsi mengajak. Mengajak merupakan tuturan yang memiliki maksud mengajak mitra tutur untuk melakukan sesuatu seperti yang dilakukan oleh penutur. Dalam dialog data (004) fungsi tuturan mengajak digunakan oleh Ellen yang menginginkan Iwan ikut bersamanya pulang. Tuturan tersebut dituturkan secara langsung melalui dialog antara Ellen dengan Iwan dalam novel Susah Sinyal. 
Fungsi tindak tutur direktif mengajak dalam novel Susah Sinyal Karya Ika Natassa dan Ernest Prakasa, terdapat pada:

Data (005)

Ellen: "Kita ngobrol di situ yuk".

Ngatno: “Ayuk!” sahut Ngatno penuh semangat. (SS, 2018: 42)

Berdasarkan konteks tuturannya, tuturan data (005) termasuk dalam fungsi tindak tutur direktif mengajak. Tuturan dituturkan oleh penutur dengan santai namun sedikit sebal karena melihat respon mitra tutur yang menurutnya terlalu bersemangat. Tuturan tersebut diungkapkan melalui bahasa tulis. Tuturan yang diucapkan menggunakan norma kesopanan dalam berkomunikasi antara si penutur dengan mitra tutur, seperti pada dialog di atas, Ellen mengajak Ngatno dan yang lain untuk mengobrol di ruang rapat. Tuturan direktif dalam dialog novel Susah Sinyal diwujudkan dalam dialog antar penutur dengan mitra tutur.

Berdasarkan analisis konteks di atas, tuturan "kita ngobrol di situ yuk" pada dialog data (005) termasuk ke dalam fungsi mengajak. Mengajak merupakan tuturan yang memiliki maksud mengajak mitra tutur untuk melakukan sesuatu seperti yang dilakukan oleh penutur. Dalam dialog data (005) fungsi tuturan mengajak digunakan oleh Ellen yang menginginkan Ngatno, Iwan, dan Astrid untuk mengobrol di sebuah ruang rapat kecil di kantor. Tuturan tersebut dituturkan secara langsung melalui dialog antara Ellen dengan Ngatno dalam novel Susah Sinyal.

\section{d. Fungsi Tindak Tutur Diektif Mengajak}

Fungsi bertanya digunakan oleh penutur untuk mengekspresikan kata-kata berupa pertanyaan dengan tujuan untuk memenuhi rasa ingin tahu, membutuhkan penjelasan dan memastikan tentang suatu hal dengan harapan mendapat respon jawaban dari pertanyaannya oleh mitra tutur. Mitra tutur tidak harus menjawab pertanyaan penutur jika mitra tutur merasa penutur tidak serius dengan pertanyaannya. Penulis menemukan 24 data yang termasuk dalam fungsi tindak tutur direktif bertanya yang ditemukan dalam novel Susah Sinyal karya Ika Natassa dan Ernest Prakasa. Beberapa diantaranya penulis analisis sebagai berikut: 


\section{Data (006)}

Ellen menyambut ponsel mamanya dan mulai menonton. Video audisi Kiara. Kening Ellen langsung berkerut melihat kata audisi di judul video itu.

Ellen: "Ma, kok 'audisi' sih? Audisi apa?"

Oma : "Ya itu, The Next Voice," jawab Oma santai. (SS, 2018: 46)

Berdasarkan analisis konteks di atas, tuturan "audisi apa?” pada dialog data (006) termasuk ke dalam fungsi bertanya. Bertanya merupakan tuturan yang memiliki maksud menanyakan kepada mitra tutur tentang apa yang ingin diketahui oleh penutur. Dalam dialog data (006) fungsi tuturan bertanya digunakan oleh Ellen yang menanyakan kepada Oma video audisi apa yang dia lihat di hp mamanya itu. Tuturan tersebut dituturkan secara langsung melalui dialog antara Ellen dengan Oma dalam novel Susah Sinyal.

Fungsi tindak tutur direktif bertanya dalam novel Susah Sinyal Karya Ika Natassa dan Ernest Prakasa, terdapat pada:

\section{Data (007)}

Abe: “Gimana, Nona suka pemandangannya?”.

Kiara mengikuti arah pandangan Abe, ke laut di dekat hotel, lalu kembali menatap Abe. Kiara: “Iya, suka.” (SS, 2018: 104)

Berdasarkan analisis konteks di atas, tuturan "gimana?" pada dialog data (007) termasuk ke dalam fungsi bertanya. Bertanya merupakan tuturan yang memiliki maksud menanyakan kepada mitra tutur tentang bagaimana penjelasan tentang sesuatu yang ingin diketahui oleh penutur. Dalam dialog data (007) fungsi tuturan bertanya digunakan oleh Abe yang menanyakan kepada Kiara bagaimana pemandangan laut di dekat hotel, apakah Kiara suka atau tidak. Tuturan tersebut dituturkan secara langsung melalui dialog antara Abe dengan Kiara dalam novel Susah Sinyal.

\section{e. Fungsi Tindak Tutur Direktif Memerintah}

Fungsi memerintah digunakan oleh penutur untuk mengekspresikan kata-kata perintah dengan tujuan untuk menyuruh mitra tutur melakukan sesuatu yang diinginkan oleh penutur. Tuturan memerintah digunakan penutur yang dalam hubungannya memiliki posisi atau kedudukan di atas mitra tutur dan merupakan alasan yang cukup 
bagi mitra tutur untuk melakukan sesuatu. Penulis menemukan 1 data yang termasuk dalam fungsi tindak tutur direktif memerintah yang ditemukan dalam novel Susah Sinyal karya Ika Natassa dan Ernest Prakasa. Data tersebut penulis analisis sebagai berikut:

\section{Data (008)}

Ellen: "Nyalain deh HP-nya," perintah Ellen.

bertubi-tubi. (SS, 2018: 152)

Kiara mengeluarkan ponsel dari saku celana pendek, menekan tombol untuk dinyalakan. Matanya yang tadinya setengah terbuka langsung membelalak melihat logo 3G muncul di sudut kiri layar ponselnya dan notifikasi mulai masuk.

Dia langsung meloncat-loncat bahagia, memeluk Ellen erat-erat sejenak lalu langsung terduduk di pasir, sibuk dengan segala chat yang masuk dan feed Instagram-nya.

Berdasarkan analisis konteks di atas, tuturan "nyalain deh HP-nya" pada dialog data (008) termasuk ke dalam fungsi memerintah. Memerintah merupakan tuturan yang memiliki maksud menyuruh mitra tutur melakukan sesuatu yang diinginkan penutur. Dalam dialog data (008) fungsi tuturan memerintah digunakan oleh Ellen yang menyuruh Kiara menyalakan HP-nya agar mendapatkan sinyal di bawah pohon di pesisir pantai. Tuturan tersebut dituturkan secara langsung melalui dialog antara Ellen dengan Kiara dalam novel Susah Sinyal.

\section{f. Fungsi Tindak Tutur Direktif Melarang}

Fungsi melarang digunakan oleh penutur untuk mengekspresikan kata-kata larangan agar mitra tutur tidak melakukan sesuatu yang tidak diinginkan oleh penutur. Penulis menemukan 2 data yang termasuk dalam fungsi tindak tutur direktif melarang yang ditemukan dalam novel Susah Sinyal karya Ika Natassa dan Ernest Prakasa. Diantaranya penulis analisis sebagai berikut:

\section{Data (011)}

Bu Sondang: "Pada jam pelajaran, jangan kau main-main apalah itu, Instajram". Kiara: "Instagram, Bu," Kiara membetulkan. (SS, 2018: 29)

Berdasarkan konteks tuturannya, tuturan data (011) termasuk dalam fungsi tindak tutur direktif melarang. Tuturan dituturkan oleh penutur kepada mitra tutur dengan suara yang terdengar menggelegar. Tuturan tersebut diungkapkan melalui bahasa tulis. 
Tuturan yang diucapkan menggunakan norma kesopanan dalam berkomunikasi antara si penutur dengan mitra tutur, seperti pada dialog di atas, Bu Sondang melarang Kiara untuk bermain Intagram di dalam kelas saat proses belajar sedang berlangsung. Tuturan direktif dalam dialog novel Susah Sinyal diwujudkan dalam dialog antara penutur dengan mitra tutur.

Berdasarkan analisis konteks di atas, tuturan "Pada jam pelajaran, jangan kau main-main apalah itu, Instajram" pada dialog data (011) termasuk ke dalam fungsi tindak tutur direktif melarang. Melarang merupakan tuturan yang memiliki

Fungsi tindak tutur direktif melarang dalam novel Susah Sinyal Karya Ika Natassa dan Ernest Prakasa, terdapat pada:

\section{Data (012)}

Iwan: "Sebagai Kepala Divisi Rumah Tangga, tugas lo jaga di depan. Nggak usah ikutikut ke ruang meeting".

Ngatno: "Kok kayak sekuriti jaga depan?".

Iwan: “Daripada jaga gawang futsal?” Iwan menjawab sekenanya. (SS, 2018: 43)

Berdasarkan konteks tuturannya, tuturan data (012) termasuk dalam fungsi tindak tutur direktif melarang. Tuturan dituturkan oleh penutur kepada mitra tutur dengan raut wajah kesal. Tuturan tersebut diungkapkan melalui bahasa tulis. Tuturan yang diucapkan menggunakan norma kesopanan dalam berkomunikasi antara si penutur dengan mitra tutur, seperti pada dialog di atas Iwan melarang Ngatno untuk ikut bersama ke ruang meeting. Tuturan direktif dalam dialog novel Susah Sinyal diwujudkan dalam dialog antara penutur dengan mitra tutur.

Berdasarkan analisis konteks di atas, tuturan "Nggak usah ikut-ikut ke ruang meeting" pada dialog data (012) termasuk ke dalam fungsi tindak tutur direktif melarang. Melarang merupakan tuturan yang memiliki maksud agar mitra tutur

\section{f. Fungsi Tindak Tutur Direktif Membolehkan}

Fungsi membolehkan digunakan oleh penutur untuk memberikan kesempatan dan kebebasan kepada mitra tutur untuk melakukan sesuatu hal. Penulis menemukan 1 data yang termasuk dalam fungsi tindak tutur direktif membolehkan yang ditemukan dalam novel Susah Sinyal karya Ika Natassa dan Ernest Prakasa. Data tersebut penulis analisis sebagai berikut: 


\section{Data (013)}

Kiara: "Gw mau ke rumah lo dong".

Jessie: "Boleh, pulang sekolah gue jemput ya. Sekalian mau bahas nih, ada produk wafer mau promo di IG lo”. (SS, 2018: 57-58)

Berdasarkan konteks tuturannya, tuturan data (013) termasuk dalam fungsi tindak tutur direktif membolehkan. Tuturan dituturkan oleh penutur kepada mitra tutur secara langsung melalui pesan singkat di HP dengan perasaan hampa, yang ada dipikirannya hanya Jessie saat itu. Tuturan tersebut diungkapkan melalui bahasa tulis. Tuturan yang diucapkan menggunakan norma kesopanan dalam berkomunikasi antara si penutur dengan mitra tutur, seperti pada dialog di atas Jessie membolehkan Kiara untuk datang ke rumahnya, lalu menjemput Kiara. Tuturan direktif dalam dialog novel Susah Sinyal diwujudkan dalam dialog antara penutur dengan mitra tutur.

\section{g. Fungsi Tindak Tutur Direktif Memaafkan}

Berdasarkan analisis konteks di atas, tuturan "Boleh, pulang sekolah gue jemput ya" pada dialog data (013) termasuk ke dalam fungsi tindak tutur direktif membolehkan. Membolehkan merupakan tuturan y. Fungsi memaafkan digunakan oleh mitra tutur untuk memberikan pengampunan atau permohonan maaf kepada penutur atau orang yang telah melakukan suatu kesalahan atas sesuatu hal. Penulis menemukan 1 data yang termasuk dalam fungsi tindak tutur direktif memaafkan yang ditemukan dalam novel Susah Sinyal karya Ika Natassa dan Ernest Prakasa. Data tersebut penulis analisis sebagai berikut:

\section{Data (014)}

Kiara: "Gue penasaran apa bokap gue juga penasaran tentang gue".

Jessie: "Kalau dia penasaran dia pasti udah cari lo, kan? Tinggal Google nama lo ini, langsung ketemu tuh Instagram lo”.

Jessie mencetuskan ini dengan spontan dan tanpa beban, sampai dia menyadari raut wajah Kiara berubah.

Jessie: "Sori, Ki, gue nggak bermaksud..."

Kiara: "Nggak apa-apa," potong Kiara, tersenyum tipis sekadar untuk menghilangkan rasa bersalah sahabatnya. (SS, 2018: 81) 
Berdasarkan konteks tuturannya, tuturan data (014) termasuk dalam fungsi tindak tutur direktif memaafkan. Tuturan dituturkan oleh mitra tutur kepada penutur dengan ekspresi tersenyum tipis, sekadar untuk menghilangkan rasa bersalah penutur. Tuturan tersebut diungkapkan melalui bahasa tulis. Tuturan yang diucapkan menggunakan norma kesopanan dalam berkomunikasi antara si penutur dengan mitra tutur, seperti pada dialog di atas Kiara memaafkan Jessie atas perkataannya yang secara spontan tidak sengaja menyakiti perasaan Kiara dan membuat raut wajah Kiara berubah. Tuturan direktif dalam dialog novel Susah Sinyal diwujudkan dalam dialog antara penutur dengan mitra tutur.

Berdasarkan analisis konteks di atas, tuturan "nggak apa-apa" pada dialog data (014) termasuk ke dalam fungsi tindak tutur direktif memaafkan. Memaafkan merupakan tuturan yang memiliki maksud agar mitra tutur memaafkan

\section{h. Fungi Tindak Tutur Direktif Menasehatkan}

Fungsi menasehatkan digunakan oleh penutur untuk mengekspresikan pemberian nasihat berupa petuah-petuah terhadap kesalahan yang dilakukan oleh mitra tutur atas sesuatu hal. Pemberian nasehat diberikan untuk membuat penutur menjadi lebih baik. Penutur berharap pemberian nasehat tersebut menjadi bahan evaluasi bagi mitra tutur untuk memperbaiki kesalahannya. Penulis menemukan 1 data yang termasuk dalam fungsi tindak tutur direktif menasehatkan yang ditemukan dalam novel Susah Sinyal karya Ika Natassa dan Ernest Prakasa. Data tersebut penulis analisis sebagai berikut:

\section{Data (015)}

Oma: "Jangan selalu ambil asumsi terburuk dalam segala hal, El, capek. Oma menyentuh tangan Ellen, membuat Ellen mengangkat pandangan, membalas tatapan mamanya. "Pikirin juga maunya Kiara. Ajak ngobrol".

Ellen: “Ajak ngobrol gimana, Ma, judes gitu sama aku”. (SS, 2018: 47)

Berdasarkan konteks tuturannya, tuturan data (015) termasuk dalam fungsi tindak tutur direktif menasehatkan. Tuturan dituturkan oleh penutur kepada mitra tutur dengan pembawaan yang lembut menunggu mitra tutur tenang. Tuturan tersebut diungkapkan melalui bahasa tulis. Tuturan yang diucapkan menggunakan norma kesopanan dalam berkomunikasi antara si penutur dengan mitra tutur, seperti pada dialog di atas Oma menasehati Ellen agar tidak selalu mengambil asumsi terburuk dalam segala hal. Dan 
memikirikan apa mau anaknya, yaitu Kiara. Ajak Kiara ngobrol. Tuturan direktif dalam dialog novel Susah Sinyal diwujudkan dalam dialog antara penutur dengan mitra tutur.

\section{i. Fungsi Tindak tutur Diektif Mengusulkan dan menyarankan}

Berdasarkan analisis konteks di atas, tuturan "Jangan selalu ambil asumsi terburuk dalam segala hal, El, capek. Pikirin maunya Kiara. Ajak ngobrol" pada dialog data (015) termasuk ke dalam fungsi tindak tutur direktif menasehatkan.

Penutur memberikan hak kepada mitra tutur untuk menerima usulan atau pendapatnya tersebut dan tidak memaksakan kehendak kepada mitra tutur untuk melakukan sesuatu. Mitra tutur juga berhak mempertimbangkan usulan dari penutur dalam mengambil suatu keputusan. Sedangkan fungsi menyarankan digunakan penutur untuk mengekspresikan pemberian saran atau anjuran. Mitra tutur dapat menerima atau menolak saran yang telah diberikan oleh penutur. Penulis menemukan 1 data yang termasuk dalam fungsi tindak tutur direktif mengusulkan dan menyarankan yang ditemukan dalam novel Susah Sinyal karya Ika Natassa dan Ernest Prakasa. Data tersebut penulis analisis sebagai berikut:

\section{Data (016)}

Bu Roslina: "Boleh saya usul?”.

Ellen mengangguk ragu.

Bu Roslina: "Kiara butuh waktu untuk memulihkan diri, dan memulihkan diri tidak pernah gampang dilakukan sendiri. Dia butuh seseorang untuk dijadikan pegangan. Dia butuh kamu”. Bu Roslina mengambil jeda sejenak sebelum melanjutkan kalimatnya, "Saran saya, kamu take a break dulu dari pekerjaan kamu, ajak Kiara liburan beberapa hari mungkin? Pergi ke tempat yang agak tenang, supaya kalian bisa punya quality time”. (SS, 2018: 72)

Berdasarkan analisis konteks di atas, tuturan "Kiara butuh waktu untuk memulihkan diri, dan memulihkan diri tidak pernah gampang dilakukan sendiri. Dia butuh seseorang untuk dijadikan pegangan. Dia butuh kamu Saran saya, kamu take a break dulu dari pekerjaan kamu, ajak Kiara liburan beberapa hari mungkin? Pergi ke tempat yang agak tenang, supaya kalian bisa punya quality time" pada dialog data (016) termasuk ke dalam fungsi tindak tutur direktif mengusulkan dan menyarankan. Mengusulkan merupakan tuturan yang memiliki maksud agar mitra tutur 
mempertimbangkan pendapat yang diberikan penutur. Dan menyarankan merupakan tuturan yang memiliki maksud agar mitra tutur dapat menerima saran atau anjuran yang diberikan oleh mitra tutur demi kebaikannya. Dalam dialog data (016) fungsi tindak tutur direktif mengusulkan dan menyarankan digunakan oleh Bu Roslina kepada Ellen dengan mengusulkan dan menyarankan Ellen untuk mempertimbangkan pendapat dan anjuran yang diberikan Bu Roslina mengenai Kiara. Tuturan tersebut dituturkan secara langsung melalui dialog antara Bu Roslina dan Ellen dalam novel Susah Sinyal.

\section{Modul Kalimat dalam Tindak Tutur Direktif}

Modus kalimat pada tindak tutur direktif dalan novel Susah Sinyal karya Ika Natassa dan Ernest Prakasa ditemukan beberapa bentuk modus kalimat, yaitu modus kalimat berita, tanya dan peritah. Penulis menganalisis data yang terdapat modus kalimat pada tindak tutur direktif tersebut, diiantaranya sebagai berikut:

\section{a. Modus Kalimat pada Tindak Tutur Direktif Meminta}

Fungsi meminta yang merupakan tuturan direktif dituturkan dengan menggunakan kalimat berita. Hal ini dapat dilihat pada data (002) berikut:

Data (002)

Ellen: “Ki, dengerin Mama dulu, please,” pintanya.

Kiara: "Dengerin apa, Ma? Dengerin pembelaan Mama? Kayak Mama selalu ngebelain klien-klien Mama itu?”. (SS, 2018: 238)

Data (002) di atas terdapat percakapan antara Ellen kepada Kiara untuk menuturkan ucapan meminta "Ki, dengerin Mama dulu, please," pintanya. Fungsi tuturan yang menyatakan meminta Ellen kepada Kiara dituturkan dengan menggunakan kalimat berita yang ditandai dengan penggunaan tanda titik di akhir kalimat. Tujuan penggunaan kalimat tersebut untuk menginformasikan atau memberitahu sesuatu atau hal seperti pada dialog di atas yang menyatakan bahwa Ellen meminta Kiara untuk mendengarkan penjelasannya dulu.

\section{b. Modus Kalimat pada Tindak Tutur Direktif Memohon}

Fungsi memohon yang merupakan tuturan direktif dituturkan dengan menggunakan kalimat berita. Hal ini dapat dilihat pada data (003) berikut: 


\section{Data (003)}

Kiara: "Oma, ayo dong”. Kiara menarik tangan neneknya ke kamar.

Oma Agatha:“Duh, Ki, males ah!”. (SS, 2018: 7)

Data (003) di atas terdapat percakapan antara Kiara kepada Oma untuk menuturkan ucapan memohon "Oma, ayo dong". Fungsi tuturan yang menyatakan memohon Kiara kepada Oma dituturkan dengan menggunakan kalimat berita yang ditandai dengan penggunaan tanda titik di akhir kalimat. Tujuan penggunaan kalimat tersebut untuk menginformasikan atau memberitahu sesuatu/hal seperti pada dialog di atas yang menyatakan bahwa Kiara memohon kepada Oma agar Oma mau ikut ke kamar bersama Kiara.

\section{c. Modus Kalimat pada Tindak Tutur Direktif Mengajak}

Fungsi mengajak yang merupakan tuturan direktif dituturkan dengan menggunakan kalimat berita. Hal ini dapat dilihat pada data (004) dan data (005) berikut:

\section{Data (004)}

Ellen: "Yuk, balik kantor ah".

Iwan: "Bentar, gue ke toilet dulu ya. Daripada nanti macet terus gue pipis di botol di mobil lo kan nggak lucu," seru Iwan sambil setengah berlari. (SS, 2018: 25)

Data (004) di atas terdapat percakapan antara Ellen kepada Iwan untuk menuturkan ucapan mengajak "yuk balik kantor ah". Fungsi tuturan yang menyatakan mengajak Ellen kepada Iwan dituturkan dengan menggunakan kalimat berita yang ditandai dengan penggunaan tanda titik di akhir kalimat. Tujuan penggunaan kalimat tersebut untuk menginformasikan atau memberitahu sesuatu/hal seperti pada dialog di atas yang menyatakan bahwa Kiara mengajak Iwan untuk pulang dari kantor bersamasama.

\section{d. Modus Kalimat pada Tindak Tutur Direktif Memerintah}

Fungsi memerintah yang merupakan tuturan direktif dituturkan dengan menggunakan kalimat berita. Hal ini dapat dilihat pada data (008) berikut:

Data (008)

Ellen: "Nyalain deh HP-nya," perintah Ellen. 
bertubi-tubi.

Kiara mengeluarkan ponsel dari saku celana pendek, menekan tombol untuk dinyalakan. Matanya yang tadinya setengah terbuka langsung membelalak melihat logo 3G muncul di sudut kiri layar ponselnya dan notifikasi mulai masuk (SS, (S.S, 2018:

Dia langsung meloncat-loncat bahagia, memeluk Ellen erat-erat sejenak lalu langsung terduduk di pasir, sibuk dengan segala chat yang masuk dan feed Instagram-nya.

Data (008) di atas terdapat percakapan antara Ellen kepada Kiara untuk menuturkan ucapan memerintah "Nyalain deh HP-nya," perintah Ellen. Fungsi tuturan yang menyatakan memerintah Ellen kepada Kiara dituturkan dengan menggunakan kalimat berita yang ditandai dengan penggunaan tanda titik di akhir kalimat. Tujuan penggunaan kalimat tersebut untuk menginformasikan atau memberitahu sesuatu/hal seperti pada dialog di atas yang menyatakan bahwa Ellen memerintah Kiara untuk menyalakan HP-nya.

\section{e. Modus Kalimat pada Tindak Tutur Direktif Melarang}

Fungsi melarang yang merupakan tuturan direktif dituturkan dengan menggunakan kalimat berita. Hal ini dapat dilihat pada data (011) dan data (012) berikut:

\section{Data (011)}

Bu Sondang: "Pada jam pelajaran, jangan kau main-main apalah itu, Instajram".

Kiara: "Instagram, Bu," Kiara membetulkan. (SS, 2018: 29)

Data (011) di atas terdapat percakapan antara Bu Sondang kepada Kiara untuk menuturkan ucapan melarang "pada jam pelajaran, jangan kau main-main apalah itu, Instagram". Fungsi tuturan yang menyatakan melarang Bu Sondang kepada Kiara dituturkan dengan menggunakan kalimat berita yang ditandai dengan penggunaan tanda titik di akhir kalimat. Tujuan penggunaan kalimat tersebut untuk menginformasikan atau memberitahu sesuatu/hal seperti pada dialog di atas yang menyatakan bahwa $\mathrm{Bu}$ Sondang melarang Kiara bermain Instagram pada saat jam pelajaran sedang berlangsung. 


\section{f. Modus Kalimat pada Tindak Tutur Direktif Membolehkan}

Fungsi membolehkan yang merupakan tuturan direktif dituturkan dengan menggunakan kalimat berita. Hal ini dapat dilihat pada data (013) berikut:

\section{Data (013)}

Kiara: "Gw mau ke rumah lo dong".

Jessie: "Boleh, pulang sekolah gue jemput ya. Sekalian mau bahas nih, ada produk wafer mau promo di IG lo". (SS, 2018: 57-58)

Data (013) di atas terdapat percakapan antara Kiara kepada Jessie untuk menuturkan ucapan membolehkan "boleh, pulang sekolah gue jemput ya". Fungsi tuturan yang menyatakan membolehkan Kiara kepada Jessie dituturkan dengan menggunakan kalimat berita yang ditandai dengan penggunaan tanda titik di akhir kalimat. Tujuan penggunaan kalimat tersebut untuk menginformasikan atau memberitahu sesuatu/hal seperti pada dialog di atas yang menyatakan bahwa Jessie membolehkan Kiara untuk datang ke rumahnya.

\section{g. Modus Kalimat pada Tindak Tutur Direktif Memaafkan}

Fungsi memaafkan yang merupakan tuturan direktif dituturkan dengan menggunakan kalimat berita. Hal ini dapat dilihat pada data (014) berikut:

\section{Data (014)}

Kiara: "Gue penasaran apa bokap gue juga penasaran tentang gue".

Jessie: "Kalau dia penasaran dia pasti udah cari lo, kan? Tinggal Google nama lo ini, langsung ketemu tuh Instagram lo”.

Jessie mencetuskan ini dengan spontan dan tanpa beban, sampai dia menyadari raut wajah Kiara berubah.

Jessie: "Sori, Ki, gue nggak bermaksud..."

Kiara: "Nggak apa-apa," potong Kiara, tersenyum tipis sekadar untuk menghilangkan rasa bersalah sahabatnya. (SS, 2018: 81)

Data (014) di atas terdapat percakapan antara Jessie kepada Kiara untuk menuturkan ucapan memaafkan "nggak apa-apa". Fungsi tuturan yang menyatakan memaafkan Jessie kepada Kiara dituturkan dengan menggunakan kalimat berita yang ditandai dengan penggunaan tanda titik di akhir kalimat. Tujuan penggunaan kalimat tersebut untuk menginformasikan atau memberitahu sesuatu atau hal seperti pada dialog 
di atas yang menyatakan bahwa Kiara memaafkan Jessie atas perkataannya yang spontan tidak sengaja membuat perasaan Kiara sedih.

\section{h. Modus Kalimat pada Tindak Tutur Direktif Menasehatkan}

Fungsi menasehatkan yang merupakan tuturan direktif dituturkan dengan menggunakan kalimat berita. Hal ini dapat dilihat pada data (015) berikut:

\section{Data (015)}

Oma: “Jangan selalu ambil asumsi terburuk dalam segala hal, El, capek. Oma menyentuh tangan Ellen, membuat Ellen mengangkat pandangan, membalas tatapan mamanya. "Pikirin juga maunya Kiara. Ajak ngobrol".

Ellen: “Ajak ngobrol gimana, Ma, judes gitu sama aku”. (SS, 2018: 47)

Data (015) di atas terdapat percakapan antara Oma kepada Ellen untuk menuturkan ucapan menasehatkan "jangan selalu ambil asumsi terburuk dalam segala hal, El, capek. Pikirin juga maunya Kiara. Ajak ngobrol”. Fungsi tuturan yang menyatakan menasehatkan Oma kepada Ellen dituturkan dengan menggunakan kalimat berita yang ditandai dengan penggunaan tanda titik di akhir kalimat. Tujuan penggunaan kalimat tersebut untuk menginformasikan atau memberitahu sesuatu/hal seperti pada dialog di atas yang menyatakan bahwa Oma menasehati Ellen agar tidak selalu mengambil asumsi terburuk dalam segala hal dan memikirkan keinginan Kiara, ajak Kiara untuk mengobrol empat mata dengannya.

\section{i. Modus Kalimat pada Tindak Tutur Direktif Mengusulkan dan Menyarankan}

Fungsi mengusulkan dan menyarankan yang merupakan tuturan direktif dituturkan dengan menggunakan kalimat berita. Hal ini dapat dilihat pada data (016) berikut:

\section{Data (016)}

Bu Roslina: "Boleh saya usul?”.

Ellen mengangguk ragu.

$\mathrm{Bu}$ Roslina: "Kiara butuh waktu untuk memulihkan diri, dan memulihkan diri tidak pernah gampang dilakukan sendiri. Dia butuh seseorang untuk dijadikan pegangan. Dia butuh kamu”. Bu Roslina mengambil jeda sejenak sebelum melanjutkan kalimatnya, "Saran saya, kamu take a break dulu dari pekerjaan kamu, ajak Kiara liburan beberapa 
hari mungkin? Pergi ke tempat yang agak tenang, supaya kalian bisa punya quality time”. (SS, 2018: 72)

Data (015) di atas terdapat percakapan antara Oma kepada Ellen untuk menuturkan ucapan mengusulkan dan menyarankan "Kiara butuh waktu untuk memulihkan diri, dan memulihkan diri tidak pernah gampang dilakukan sendiri. Dia butuh seseorang untuk dijadikan pegangan. Dia butuh kamu. Saran saya, kamu take a break dulu dari pekerjaan kamu, ajak Kiara liburan beberapa hari mungkin? Pergi ke tempat yang agak tenang, supaya kalian bisa punya quality time". Fungsi tuturan yang menyatakan mengusulkan dan menyarankan Bu Roslina kepada Ellen dituturkan dengan menggunakan kalimat berita yang ditandai dengan penggunaan tanda titik di akhir kalimat. Tujuan penggunaan kalimat tersebut untuk menginformasikan atau memberitahu sesuatu/hal seperti pada dialog di atas yang menyatakan bahwa $\mathrm{Bu}$ Roslina mengusulkan dan menyarankan kepada Ellen untuk istirahat dulu dalam pekerjaannya dan mengajak Kiara liburan agar Kiara dapat memulihkan dirinya seperti sedia kala dan Ellen bisa quality time bersama Kiara.

\section{j. Modus Kalimat pada Tindak Tutur Direktif Bertanya}

Fungsi bertanya yang merupakan tuturan direktif dituturkan dengan menggunakan kalimat tanya. Hal ini dapat dilihat pada data (006) dan data (007) berikut:

\section{Data (006)}

Ellen menyambut ponsel mamanya dan mulai menonton. Video audisi Kiara. Kening Ellen langsung berkerut melihat kata audisi di judul video itu.

Ellen: "Ma, kok 'audisi' sih? Audisi apa?"

Oma : "Ya itu, The Next Voice," jawab Oma santai. (SS, 2018: 46)

Data (006) di atas terdapat percakapan antara Ellen kepada Oma untuk menuturkan ucapan bertanya "audisi apa?". Kalimat tanya tersebut termasuk kalimat tanya Wh Questions yang merupakan pertanyaan untuk meminta informasi. Informasi yang diminta berupa tempat, waktu, orang, hal, cara, alasan ataupun benda. Fungsi tuturan yang menyatakan bertanya Ellen kepada Oma dituturkan dengan menggunakan kalimat tanya yang ditandai dengan penggunaan tanda tanya diakhir kalimat. Tujuan penggunaan kalimat untuk menanyakan sesuatu/hal yang sesuai dengan apa yang 
terkandung dalam suatu kalimat seperti pada dialog di atas, Ellen yang menanyakan kepada Oma tentang audisi apa yang dia lihat dalam video di HP mamanya itu.

\section{k. Modus Kalimat pada Tindak Tutur Direktif Meminta}

Fungsi meminta yang merupakan tuturan direktif dituturkan dengan menggunakan kalimat tanya dan perintah. Hal ini dapat dilihat pada data (001) berikut:

\section{Data (001)}

Jessie: "Eh, betewe, headband lo ini masih ada nggak? Buat gue dong!"

Kiara tersenyum tengil.

Kiara: "Minta dibikinin sama oma lo dong". (SS, 2018: 19)

Data (001) di atas terdapat percakapan antara Jessie kepada Kiara untuk menuturkan ucapan menuntut "headband lo ini masih ada nggak? Buat gue dong!" Fungsi tuturan yang menyatakan meminta Jessie kepada Kiara yang dituturkan dengan menggunakan kalimat tanya dan perintah yang ditandai dengan penggunaan tanda tanya dan tanda seru di akhir kalimat. Tujuan penggunaan kalimat tanya untuk menanyakan sesuatu/hal yang sesuai dengan apa yang terkandung dalam suatu kalimat. Dan tujuan penggunaan kalimat perintah untuk memerintah/menyuruh lawan bicara tentang sesuatu/hal seperti pada dialog di atas yang menyatakan bahwa Jessie menanyakan kepada Kiara apakah Kiara mempunyai ikat kepala (headband) sekaligus memerintah Kiara untuk memberikan headband miliknya kepada Jessie.

\section{Modus Kalimat pada Tindak Tutur Direktif Menuntut}

Fungsi menuntut yang merupakan tuturan direktif dituturkan dengan menggunakan kalimat tanya dan perintah. Hal ini dapat dilihat pada data (009) dan data (010) berikut:

\section{Data (009)}

Kiara: "Papa salah apa?!” tuntut Kiara.

Ellen: “Mama yang salah!”. (SS, 2018: 240)

Data (009) di atas terdapat percakapan antara Kiara kepada Ellen untuk menuturkan ucapan menuntut "Papa salah apa?!” Fungsi tuturan yang menyatakan menuntut Kiara kepada Ellen yang dituturkan dengan menggunakan kalimat tanya dan perintah yang ditandai dengan penggunaan tanda tanya dan tanda seru di akhir kalimat. 
Tujuan penggunaan kalimat tanya untuk menanyakan sesuatu/hal yang sesuai dengan apa yang terkandung dalam suatu kalimat. Dan tujuan penggunaan kalimat perintah untuk memerintah/menyuruh lawan bicara tentang sesuatu/hal seperti pada dialog di atas yang menyatakan bahwa Kiara menanyakan Papanya salah apa sekaligus memerintah Ellen untuk menjelaskan kepadanya tentang apa yang belum Kiara ketahui tentang Papanya selama ini.

\section{Simpulan}

Berdasarkan hasil penelitian dan pembahasan yang terdapat pada bab IV yang sesuai dengan rumusan masalah dan tujuan penelitian, maka dapat disimpulkan bahwa hasil dalam penelitian ini meliputi dua pembahasan yaitu fungsi tindak tutur direktif dan modus kalimat pada tindak tutur direktif dalam novel Susah Sinyal karya Ika Natassa dan Ernest Prakasa. Data yang ditemukan dalam penelitian ini berjumlah 40 data, yang diperoleh dari dialog percakapan antartokoh dalam novel. Fungsi tindak tutur direktif yang ditemukan dalam novel Susah Sinyal karya Ika Natassa dan Ernest Prakasa yaitu fungsi meminta sebanyak 2 data, memohon 1 data, mengajak sebanyak 4 data, bertanya sebanyak 24 data, memerintah 1 data, menuntut sebanyak 2 data, melarang sebanyak 2 data, membolehkan 1 data, memaafkan 1 data, menasehatkan 1 data, mengusulkan dan menyarankan 1 data.

Selanjutnya, modus kalimat pada tindak tutur direktif yang ditemukan dalam novel Susah Sinyal karya Ika Natassa dan Ernest Prakasa yaitu modus kalimat berita, tanya, perintah dan kalimat tanya \& perintah. Data yang mengandung modus kalimat tersebut antara lain yaitu kalimat berita sebanyak 11 data, kalimat tanya sebanyak 25 data, kalimat perintah 1 data dan kalimat tanya \& perintah sebanyak 3 data.

\section{Daftar Pustaka}

Chaer. Abdul. 2010. Kesantunan Berbahasa. Jakarta: Rineka Cipta

Chaer, Abdul dan Leonie Agustina. 2004. Sosiolinguistik Perkenalan Awal (Revisi Ed). Jakarta: Rineka Cipta

Ibrahim, Abd. Syukur. 1993. Kajian Tindak Tutur. Surabaya: Usaha Nasional

Moleong, Lexi J. 2010. Metode Penelitian Kualitatif. Bandung: PT Remaja Rosdakarya 
Mulyana. 2005. Kajian Wacana. Yogyakarta: Tiara Wacana.

Nadar, FX. 2008. Pragmatik dan Penelitian Pragmatik. Yogyakarta: Graha Ilmu.

Prayitno, Harun Joko. 2011. Kesantunan Sosiopragmatik. Surakarta: Universitas Muhammadiah Press.

Rohmadi. Muhammad. 2004. Pragmatik Teori Analisis. Yogyakarta: Lingkar Media.

Sudaryanto. 1992. Metode Linguistik: Ke Arah Memahami Metode Linguistik. Yogyakarta: Gadjah Mada University Press.

Tarigan, Henry Guntur. 1990. Pengajaran Pragmatik. Bandung. Penerbit Angkasa.

Wijana, I Dewa Putu. 1996. Dasar-dasar Pragmatik. Yogyakarta: Andi Offset.

Wijana, I Dewa Putu dan Muhammad Rohmadi. 2011. Sosiolinguistik Kajian Teori dan Analisis. Yogyakarta: Pustaka Pelajar.

Yule, George. 2006. Pragmatik. Yogyakarta: Pustaka Pelajar.

Anisa Ulfah, Nurhadi, dan Muakibatul Hasanah. 2016. Wujud Kesantunan Tindak Direktif Guru Taman Kanak-kanak. Jurnal Pendidikan. Vol.1, No 6:1008-1016 EISSN 2502-471X

Ardianto. 2013. Tindak Tutur Direktif Guru dalam Wacana Interaksi Kelas Anak Tunarungu. Jurnal LITERA:Jurnal Penelitian Bahasa, Sastra, dan Pengajarannya. Vol. 12, No 1 ISSN 1412-2596

dan Pengajarannya. Vol. 3, No 1:79-97 PISSN 2442-7632 EISSN 2442-9287. 